\title{
The Russian Orthodox Church, State and Society in 1991-1993: the Rest of the Story
}

\author{
WILLIAM VAN DEN BERCKEN
}

The year 1991 should have been the happiest one for the Russian Orthodox Church since 1917. The church finally saw the end of a state which had fought or obstructed it for 70 years. Even after the legal restoration of religious freedom in October 1990 , when ideologically based restrictions on religion were abolished, the state apparatus of control had continued to exist in the shape of the Council for Religious Affairs and the KGB's department for the church. By the end of 1991, when the Soviet state as such was abolished, these institutions also disappeared. For the first time since the revolution, the churches in Russia were now really free to perform their religious task without any hindrance by governmental control.

The dissolution of the Soviet state, however, in contrast to that of communist ideology, has paradoxically led to new external and internal problems for the Russian Orthodox Church. The institutional interests of the Moscow Patriarchate had always corresponded with those of the multinational Soviet state. The collapse of the Soviet Union into a number of independent states confronted the Russian Orthodox Church not only with organisational problems with regard to the Orthodox Church in former Soviet republics but also with a kind of political identity crisis in the new pluralistic Russian society.

\section{The Church and the Russian State}

In spite of division among the leadership of the church during the coup of August 1991 and disclosures about the long-term cooperation of some highranking metropolitans with the KGB, the Orthodox Church in post-Soviet Russia enjoyed wide popularity. At his inauguration as the first Russian president in June 1991, Boris Yel'tsin had himself blessed by Patriarch Aleksi II. A positive attitude towards the Orthodox Church was expressed by the Russian minister of justice on 30 May 1991 at the official registration of the Civil Statute of the Russian Orthodox Church, a result of the new law on religious freedom of October 1990. He gave 'as his personal opinion and that of his staff and not as that of the state' that Orthodoxy should be the primary religion for Russian citizens. ${ }^{1}$

Church and state were faced with a common task in the renewal of Russian society. Gorbachev had recognised that the church as a source of ethical and cultural values was indispensable for counteracting the moral disintegration of communist society, and this is even more obviously the case now that communism has disappeared. But whether it is also up to the church to speak, for example, in favour of the unity of the former Soviet army is another matter. This is what Metropolitan Kirill was understood 
to be doing while addressing 4,000 officers in the Kremlin in January 1992. Although Kirill gave priority to the human problems in the army, his speech can easily be misused ideologically, as demonstrated by its publication in the radical right-wing newspaper Russky vestnik. ${ }^{2}$ In right-wing circles the church is increasingly placed within the framework of Russian nationalism, and the need to preserve the true faith of the Russian church is used in arguments against democracy and 'cosmopolitan' influences. The main agitator in this respect is the weekly Russky vestnik, which was established in January 1991. It preaches a religious and political chauvinism which is antiwestern as well as antiecumenical and especially anti-Catholic. With pictures of icons and saints and quotations from the patriarch which have been taken out of context, it fosters a frightening form of religious ethnocentrism.

Russky vestnik hâs a fairly large circulation (some 200,000 copies). There are also a large number of smaller papers which appear irregularly and which usurp Russian Orthodoxy for an even more extreme form of nationalism: 'for Faith, Tsar and Fatherland', as the slogan reads on one title page. Church banners and icons are regularly carried in demonstrations by National Bolsheviks and other conservative factions which aspire to the restoration of the ancient Soviet empire.

During 1991 Patriarch Aleksi II repeatedly cautioned against abuse of the church for political purposes. In this respect, after the unfortunate incident of his signature on a conservative manifesto in December 1990, he has grown into a diplomatic leader with an eye for the mistakes of the church in the past. ${ }^{3}$ He normally adopts a neutral position in political disputes, but protested sharply against the use of violence by Soviet troops in Vilnius in January $1991 .{ }^{4}$ In an interview in Komsomol'skaya pravda he spoke out against 'wild national consciousness, antisemitism, ideological canonisation of the tsar and idealisation of the monarchy'. ${ }^{5}$ In an interview in Izvestiya he expressed his concern about the danger of the 'politicising' of the church as an institution and about its involvement in election campaigns. He defended the 'suprapolitical' character of the church and warned against a marriage between church and state, quoting the words of Cardinal Sin of Manila: 'When the church contracts a "political marriage" with one or other political forces, she may well become a "widow" in the next generation.' In another interview, on the occasion of the first anniversary of his appointment as patriarch, Aleksi II dissociated himself from the 'declaration of loyalty' to the Soviet system issued by Metropolitan Sergi in 1927. While recognising the good intentions of his predecessor, Aleksi stated that the declaration 'has on the whole become a thing of the past, and we are no longer guided by it'. When the interviewer quoted the so-called Furov Report from the 1970s, in which Aleksi is named as one of the bishops showing great loyalty towards the state, Aleksi asked for forgiveness and understanding for his attitude at the time. With regard to the painful problem of the division of the Russian church into a foreign and a Moscow jurisdiction, Aleksi no longer saw any reason for that, now that the church in Russia was no longer politically committed. "There can be no "free Russian Church", "liberal Russian Church", "monarchist Russian Church” . ..'7

On 27 December 1991 the Synod of the Russian Orthodox Church issued a declaration on the occasion of the abolition of the USSR. It expresses the hope that the three Slavonic peoples will remain spiritually connected with each other on the basis of their common origin in Kiev-Rus' and that the Commonwealth may develop in a positive direction. The Moscow Patriarchate does not want to occupy any preferential political or ideological position in the Commonwealth. The declaration ends with the prayer that God 'may not blame us for the sins of our forefathers'. ${ }^{8}$ 


\section{Further Polarisation}

During 1992 the political polarisation in postcommunist Russia had its effect on the Orthodox Church. The use of Orthodoxy for nationalistic sentiments became a very serious problem for the church. Apart from general warnings by the patriarch, consistent opposition against this comes from lay believers. The Christian publicist Zoya Krakhmal'nikova has written emotive articles warning against the new political temptations facing the church. She points out the neopagan and degenerate nature of a nationalistic Orthodoxy, and Russia's continuous loss of faith as a result of the combination of religion and neobolshevism. ${ }^{9}$ Together with Aleksandr Nezhny and Sergei Lezov she has founded an association called 'A Christian Alternative to Russian Fascism'. The new philosophical journal Put' has published criticism of nationalism from a Christian point of view. ${ }^{10}$ It is a pity that such clear and unambiguous critical material is not to be found in periodicals published by the church. Nor does one find in the church press any attempt to cope with the past similar to the discussion published in Ogonek dealing with the links between church and KGB. The discussion was chaired by the journalist Aleksandr Nezhny, and participants included Zoya Krakhmal'nikova, the members of parliament and priests Vyacheslav Polosin and Gleb Yakunin, another member of parliament Lev Ponomarev, the head of the patriarchate's Department for Religious Education Fr Ioann Ekonomtsev, deacon Andrei Kurayev, the priests Georgi Edel'shtein and Nikolai Artemov (the latter of the Russian Orthodox Church Abroad) and the lawyer Yuri Rozenbaum. The patriarchate was criticised by the former dissidents for attempting to prevent any legal inquiry into its relations with the KGB, and more generally for the past policies of the church leadership. The representative of the patriarchate offered a defence. ${ }^{11}$

Two striking examples of churchmen espousing extreme nationalism are the priest Dmitri Dudko and Metropolitan Ioann of St Petersburg. Dudko was a courageous preacher of the faith in the 1970s, but for some years now he has been proclaiming a nationalist Christianity. He has even become the 'spiritual mentor' of the extreme right-wing newspaper Den', in which he preaches against 'reformers and pagans' and against Catholics and Protestants who 'are destroying Orthodox Russia'. ${ }^{2}$ Equally regrettable is the attitude of Metropolitan Ioann. He believes the Jews to be one of the causes of Russia's downfall, and as an argument for the canonisation of Nicholas II he advances the 'fact' that the tsar fell as a ritual victim to the Jews. ${ }^{13}$ Russky vestnik has praised Metropolitan Ioann for his firm stand with respect to the Jewish 'conspiracy' against present-day Russia. ${ }^{14}$ In an open letter Metropolitan Ioann has called on the mayor of St Petersburg to ban the activities of the 'false prophets' of 'pseudo-Christian' western sects in his city. What is special is not the fact that Metropolitan Ioann is turning against western sects - Patriarch Aleksi and Metropolitan Kirill frequently do the same, and often with justification - but the pathologically chauvinist terminology he uses. ${ }^{15}$ Extreme nationalist booklets have been republished 'with the blessing of Metropolitan Ioann', including Russkaya ideologiya (The Russian Ideology), a work written in 1939 by Archbishop Serafim Sobolev of the Russian Orthodox Church Abroad, and Svyataya Rus' (Holy Russia), a booklet by N. D. Tal'berg first published in Paris in 1929.

Religious nationalism is promoting a rapprochement between the right wing of the Russian Orthodox Church of the Moscow Patriarchate and that of the Russian Orthodox Church Abroad, which in Russia calls itself the 'Free Orthodox Church'. Aleksi Averyanov, a priest of the Free Orthodox Church working in Moscow, and Bishop Varnava of Cannes have both maintained public contacts with the anti-Jewish 
association Pamyat'. Metropolitan Vitali of New York, head of the Russian Orthodox Church Abroad, and Bishop Valentin of Suzdal' of the Free Orthodox Church have, it is true, declared themselves openly against antisemitism, but not against Pamyat' as such. ${ }^{16}$

In November 1991 Patriarch Aleksi addressed American rabbis in New York. His speech was an impressive testimony to Christian-Jewish solidarity. The patriarch emphasised the religious affinity between Christianity and Judaism and condemned antisemitism in his homeland. The address was published not in the church press but in Moskovskiye novosti. ${ }^{17}$ In an open letter to the patriarch, right-wing Orthodox urged him to dissociate himself from his speech and to emphasise a nationalist line on behalf of the church. ${ }^{18}$

It is clear that on this issue there is a difference of opinion between Patriarch Aleksi and Metropolitan Ioann. The patriarch has not allowed Metropolitan Ioann to publish his views in the official church press, but he cannot dismiss him. If he tried to do so the metropolitan might go over to the Free Orthodox Church, and there might even be danger of a schism. ${ }^{19}$

One particular issue which clearly demonstrates different attitudes towards nationalism within the church is the canonisation of Tsar Nicholas II. At its session in April 1992 the Bishops' Council of the Russian Orthodox Church announced a study on the possible canonisation of the last tsar and his family. In contrast to the Russian Orthodox Church Abroad, which canonised Nicholas II in 1982, the Moscow Patriarchate is still hesitating. The old reason, the hostile Soviet ideology, has given way to purely ecclesiastical considerations. Meanwhile, in many places in Russia the last tsar is already being venerated as a saint, and his icon is carried in nationalistic demonstrations. Deacon Andrei Kurayev criticises nationalistic canonisations in the church. ${ }^{20} \mathrm{He}$ alludes particularly to the canonisation in 1988 of Prince Dmitri Donskoy, 'who was not by any means always an example of Christian politics'. And now, he comments, any doubts expressed about the possible canonisation of Nicholas II are considered 'indecent, unpatriotic and not in keeping with the church'. Kurayev questions the appropriateness of the expression 'tsar-martyr' on the grounds that Nicholas was a bad ruler. His cruel death does not make up for his record of inadequate administration of the country and does not make him into the paragon of an 'Orthodox tsar' and a 'responsible Christian politician'. Besides, he did not die for the faith, but was killed for political reasons. It is only those who believe in a Jewish conspiracy against Orthodox Russia who regard him as the victim of a religious murder. The possible canonisation of Nicholas II was also criticised in an open letter to the Bishops' Council, published in the weekly Ogonek, in which the historian Mikhail Krivov refers to the innocent victims who suffered because of Tsar Nicholas' policies and also criticises Nicholas' form of religiosity, which was distorted by spiritism and the influence of Rasputin. ${ }^{21}$

\section{Renewal of Church Life}

It is hardly possible to keep count of the number of church buildings that have been given back by the state to the Moscow Patriarchate. Exact figures are difficult to arrive at, because of the jurisdictional confusion in Ukraine, for example, and because it is often not clearly indicated to what date a particular statistic refers. It is, however, certain that by the end of 1991 the number of church buildings was almost double that of 1988 - from 6,700 to more than 12,000 - and that approximately 50 per cent of 
the churches of the Russian Orthodox Church were to be found on Ukrainian territory. A total separation of Ukraine was clearly going to be a significant blow to the Moscow Patriarchate.

There has been an enormous nominal increase in the number of monasteries, from 19 to 118 . But these are for the most part in a half ruinous condition, often still empty or inhabited by a mere handful of monks or nuns organising the restoration. Some of these buildings are important from a historical point of view. The best-known in Moscow is the Donskoy Monastery, dating from 1593, which was given back in April 1991, except for the Great Cathedral, at that time a sculpture museum, which was not given back until August. This is the church where Patriarch Tikhon has been reburied. This great event in Russian church life was one of the unexpected consequences of a big fire on 19 November 1991 in the Small Cathedral of the Donskoy monastery. Arson is suspected.22 We shall return to this subject later on. Other monasteries restored in Moscow are the Novo-Spassky Monastery and the Visoko-Petrovsky Monastery. The latter, in the centre of the city, has become the seat of the new Department for Religious Education and Catechesis.

Of the other churches in Russia which were returned in 1991 it is worth mentioning the famous eleventh-century Sofia Cathedral in Novgorod, which was reconsecrated by the patriarch in a ceremony redolent with a sense of history, and the Yur'yev monastery church, dating from 1119, in the same city. ${ }^{23}$ These Novgorod monuments are now Russia's oldest cathedral and monastic church: the still older Sofia Cathedral and the Monastery of the Caves in Kiev are in independent Ukraine. The reopened Monastery of the Birth of the Mother of God in Vladimir also dates from the twelfth century. It is to house a theological college. An important impulse for the restoration of the Valaamo Monastery was provided by the visit of Patriarch Aleksi and President Yel'tsin on 11 and 12 July 1992. This thirteenth-century monastery, on an island in Lake Ladoga, belonged to Finland between the two world wars. It was closed after Karelia became Russian territory. Now part of it is back in use again. The monastery, surrounded by unspoilt nature, impressed Yel'tsin as a piece of paradise. After the distinguished guests had left, however, "there were still drunkards hanging about on the quay and dirty children were begging the Finns there for cigarettes and chewing-gum and even for what was left of a banana.'24

Another historic monastery which is being restored to its original state is the Solovetsky Monastery on an island in the White Sea in the extreme north of Russia. It was one of the first Soviet concentration camps in the 1920s. In the 1930s virtually the whole of the Russian episcopate was imprisoned here. In August the relics of the three fifteenth-century founders of the monastery, the saints Zosima, Savvati and German, were solemnly brought back from St Petersburg, where for decades they had lain in the Museum of Atheism, before being moved to the Aleksandr Nevsky monastery in 1990. The ceremony took place in the presence of Patriarch Aleksi, the Bishop of Archangel'sk and the local political and military authorities. At the same time there was a commemoration of the victims of religious persecution and an exhibition on the theme in the monastery. On the historical significance of this event the reporter in Ofitsial'naya khronika philosophises:

When you look at it from outside, it is hard to see what can be historical about the coming of the patriarch to these small northern islands, where there is a half-neglected 'architectural monument', where in the only shop there is a perpetual queue for hard liquor and cheap alarm clocks, and where 
- paradoxically - besides old churches one can hardly find a hundred

believers nowadays. But 'My strength shows itself in weakness.' 25

On 25 July 1991 the Moscow municipal authorities in principle gave back to the Russian Orthodox Church all its former church buildings in the city - a total of 175 . The effect of this decision will inevitably involve many practical problems. The firms which now occupy the buildings will have to move out. ${ }^{26}$ In an interview in Izvestiya (10 June 1991) the Patriarch said that the church had already regained ownership of 130 church buildings, but that many of them were in such a bad state that they would virtually have to be rebuilt. Rebuilding has indeed already started, as any visitor to Moscow can see. In view of the alarming decay of many buildings in Moscow (and other cities) it is remarkable how many church buildings are in scaffolding. The economic reform of January 1992 and subsequent inflation has, however, made comprehensive reconstruction problematical. This applies particularly to some of the large historical reconstruction projects which were planned earlier, such as the building of a big church in south-west Moscow to commemorate the millennium of Russian Christianity, the rebuilding of the huge Church of Christ the Saviour in the centre of Moscow, generally considered a totally unrealistic project, and the rebuilding of the Uspensky Cathedral in the Kiev Monastery of the Caves, for which the then Metropolitan Filaret and Leonid Kravchuk laid the foundation stone on 8 April $1991 .{ }^{27}$

A special case are the churches in the Kremlin. The status of these precious monuments of Russian culture has been a longstanding topic of discussion between the Russian government and the Moscow Patriarchate. On 14 November 1991 the patriarchate was given the use of them by a presidential decree. ${ }^{28}$ Now the Dormition (Uspensky) Cathedral is once more the principal church of Russian Orthodoxy. A significant occasion was the first celebration since 1917 of the Feast of the Dormition in the cathedral on 28 August 1991, shortly after the failed coup. But the status of the Kremlin churches was finally resolved only one year later when, on 15 November 1992 , Patriarch Aleksi and the Russian Minister of Culture Sidorov reached an agreement about the use of the church buildings in the Kremlin and on Red Square. The patriarchate has been granted permanent free use of the following church buildings: the Cathedral of the Dormition of the Mother of God, the Cathedral of the Annunciation, the Cathedral of the Archangel, the Church of the Twelve Apostles, the Church of the Deposition of the Robe and the Church of the Intercession (or St Basil's Cathedral). The ministry is to undertake the maintenance of these churches and the protection of the art treasures they contain. The patriarchate is to pay a few museum employees in the churches. Apart from religious services the churches are to remain open to the public. Concerts or other non-religious activities, however, will not take place in the buildings. In order to protect the frescoes and icons the number of churchgoers and visitors may sometimes by limited. ${ }^{29}$

The protection of church art constitutes an entirely new common problem for church and state. There are frequent reports in the media about icons and other objects having been stolen from church buildings, mostly with a view to being sold abroad. A statement by the Ministry of State Security shows how serious the problem is: on average there are about 2,000 cases of theft from church buildings every year and it is estimated that 80 per cent of the icons have already been smuggled out of the country. ${ }^{30}$ Meanwhile the patriarch has complained that there are conflicts between institutions of church and state over former church libraries and archives seized by the Soviet authorities. ${ }^{31}$ 


\section{Regaining the Saints}

Apart from church buildings the Russian Orthodox Church is also regaining its saints. This is true in a very literal sense. The relics of two saints, Serafim of Sarov and Patriarch Tikhon, have been rediscovered.

The finding and reburial of Saint Serafim was a grand occasion. ${ }^{32}$ This eighteenthcentury monk was canonised in 1903, in the presence of the tsar's family, and buried again in the church at Sarov, which had been built in honour of him. For two decades his tomb was a popular place of pilgrimage. In 1922, Serafim's body was removed from the tomb in the course of an antireligious campaign, and transferred to a museum of religious art in the Donskoy monastery in Moscow. When this museum was closed, the relics were taken to the main museum of atheism in Moscow. This museum was closed in turn, and its contents were transferred to the atheist museum in Leningrad, but by this time the saint's relics were not to be found. They were rediscovered during a general clearance of the museum in 1991. After official confirmation by a church commission that the relics were indeed the bodily remains of St Serafim, the body was taken to the Trinity Cathedral of the Aleksandr Nevsky monastery, and on 6 February 1992 carried in solemn procession to the station, and taken to Moscow by train. Here it was placed in the patriarchal Epiphany Cathedral for public veneration until July, and at the end of that month, amid great public and media interest, it was reburied in the restored Diveyevo monastery near Nizhni Novgorod, whence it had been removed in 1922.

After the canonisation of Patriarch Tikhon in 1989 it was a matter of distress for the church that it was uncertain about where Tikhon's body was buried. His tomb in the Small Cathedral of the Donskoy monastery was known to be empty. According to the official version the body had been cremated, but according to others it had been buried in an unknown place. The restoration of the Small Cathedral after the fire of November 1991 provided the opportunity for a search under the tomb. On 19 February 1992 the actual coffin was found a few metres down. It appeared that it had been deliberately buried in this way in 1925 in order to prevent robbery. On 5 April Patriarch Tikhon was reburied, this time in the Great Cathedral of the monastery, in the presence of all the bishops, who had assembled there for a council. ${ }^{33}$

The canonisation of Tikhon meant an end to the church's longstanding silence about the believers who had fallen victim to persecution under Lenin. In June 1990 the Local Council of the Russian Orthodox Church set up a commission for the canonisation of the 'new martyrs', under the chairmanship of Metropolitan Yuvenali. On 3 April 1991 a memorial plaque to all the martyrs of the Soviet period was unveiled in the Donskoy monastery. The officiating priest called the persecution of the church in twentieth-century Russia 'the most serious in the history of the church'. ${ }^{34}$

Other prominent victims were now rehabilitated. In 1991 the above-mentioned canonisation commission reported on its inquiry into Metropolitan Vladimir of Kiev, shot dead by an armed gang in the Kiev Monastery of the Caves on 25 January 1918, and Metropolitan Veniamin of Petrograd, executed by firing squad on 13 August 1922 after a show trial during the campaign for the seizure of church property. Metropolitan Veniamin and 58 others who had been sentenced with him in 1922 had already been officially rehabilitated by the Supreme Court of the Russian Federation on 31 October 1990. ${ }^{35}$

At the session of the Holy Synod of 25 December 1991 Metropolitan Yuvenali's commission submitted the official biographies of the proposed new saints for approval. These were: the two aforementioned metropolitans; the three men executed 
together with Veniamin, i.e. the priest Sergi (former Duma member Vasili Shein), Yuri Novitsky (professor of law at Petrograd University) and the lawyer Ivan Kovsharov; Grand Duchess Yelizaveta; the novice Varvara who had been killed with her in 1918; and the parents of St Sergi of Radonezh. Yelizaveta was a German princess, the sister of Tsaritsa Aleksandra, and married to Grand Duke Sergei Romanov. After the murder of her husband in 1905 she took her religious vows and founded a hospital in Moscow, where she worked until the revolution. On 18 July 1918, together with some other members of the imperial family, she was thrown alive into a mine shaft. During the civil war her body was transferred to Jerusalem, where it was buried in a Russian monastery founded by her husband. All these candidates were canonised at the Bishops' Council of 4 April 1992. At the ceremony it was stated that in these first canonised martyrs of twentieth-century Russia the countless other victims were also honoured.

A very important event in the historically conscious life of the Russian Orthodox Church as well of the Russian state was the 600th anniversary in 1992 of the death of St Sergi of Radonezh. The memorial ceremonies started in Vologda on 13 August with a conference in the restored monastery of one of Sergi's disciples, the Spaso-Prilutsky Monastery. From 2 to 11 October a series of events took place in Moscow and Sergiyev Posad (as Zagorsk has been renamed since September 1991): a scholarly symposium on Sergi in the Danilov Monastery; two exhibitions of icons, manuscripts and religious art, organised in cooperation with the Ministry of Culture; a concert of Orthodox church music in the Academy of Music; a meeting in the Moscow Trade Unions' House with representatives of other churches, social bodies and the government; and a reception in the Kremlin palace, where President Yel'tsin observed that this was the first religious event in the buildings of the Kremlin for 75 years. It was followed by a religious commemoration in the Trinity-St Sergius Monastery, attended by the leaders of the Ukrainian, Belorussian and American Orthodox Churches and tens of thousands of believers. The series of ceremonies ended with the inauguration of an orphanage in Khopkovo, where the parents of Sergi of Radonezh lie buried. The whole celebration was a national cultural-religious event in which cooperation between church and state was obvious and complete.

A similar natural cooperation marked the solemn erection of a monument in honour of SS Cyril and Methodius on 24 May, the saints' feastday now celebrated as the Day of Slavonic Script and Culture. On Slavyansky Square (former Nogin Square), in front of the former building of the Central Committee, the patriarch and a number of civil dignitaries together unveiled a double statue of the saints equipped with a big cross.

\section{Social Work}

Completely unprepared, the Russian Orthodox Church has become active in the field of pastoral, educational and diaconal work. There are too few priests, teachers and social workers for all the tasks and inadequate material means, premises, literature and money. Work has to be organised from the ground, under extremely difficult economic conditions.

\section{Publishing}

Bibles, books on religious instruction, liturgical books, patristic literature, church histories and hagiographic literature are on sale at book stalls, but they are mainly 
reprints of prerevolutionary books and the prices are very high. The patriarchate is looking for ways of cooperating with existing publishing firms.

On 20 November 1991 the patriarchate's Department for Religious Education and Catechesis took part in an ecumenical meeting on religious literature, as part of a literature exhibition in the Moscow Library for Foreign Literature organised by the Benedictine monastery of Chèvetogne. Speakers were Ioann Ekonomtsev, head of the department, Michel van Parys, abbot of Chèvetogne, Innokenti Pavlov, chairman of the patriarchal Bible commission, the Baptist leader Aleksei Bychkov and the Dutch Rabbi A. Soetendorp. The exhibition was also visited by the Metropolitans Yuvenali and Kirill. The meeting gave hopeful ecumenical signals. ${ }^{36}$

At a conference in the Danilov Monastery from 7 to 11 December 1991, sponsored by the World Council of Churches, it was decided to publish an edition of five books of religious instruction for different age groups and to organise diocesan courses for catechists. The conference was attended by representatives of the Bible commission, of the Orthodox brotherhoods and of Orthodox youth organisations as well as leaders of Sunday schools, professors and representatives of other Orthodox churches. It was led by the Orthodox theologian Nikolai Lossky from Paris. Meanwhile the Department for Religious Education and Catechesis has found accommodation in the VisokoPetrovsky Monastery, which is still in the process of restoration. ${ }^{37}$

On 1 November 1991 a Bible House was opened on Pyatnitskaya ulitsa in Moscow. It is run by the Russian Bible Association, founded in January 1990, and is an example of practical ecumenical cooperation. The opening was attended by Patriarch Aleksi, the vice-chairman of the Council of Evangelical Christians and Baptists Aleksei Bychkov, the secretary-general of the United Bible Societies John Ericson, the chairman of the Library of Congress James Billington and the Russian deputy prime minister Saburov. At a later date, on 11 January 1992, the Catholic vice-chairman of the United Bible Societies, the Italian bishop Ablondi, also visited the Russian Bible Association. ${ }^{38}$ At the end of 1992 the Moscow Patriarchate had about ten bookshops in the capital for the distribution of its own literature, but active parish churches also sell literature in their own shops.

More than 20 Orthodox periodicals were being published in Russian in 1991, albeit very irregularly. Several of these are refounded diocesan periodicals (Yeparkhial'nyye vedomosti), such as those of Moscow, St Petersburg, Samara, Saratov and Tver'. Apart from these, the periodical publications of the theological academies of St Petersburg and Moscow have begun appearing again, and a few diocesan magazines, such as that of Kostroma. The only national religious periodicals are Pravoslavnaya beseda, founded in 1991, and Moskovsky tserkovny vestnik, which was first published in 1989. This last, the only national church weekly, was in danger of liquidation as a result of mismanagement. The head of the Department for Publishing of the Moscow Patriarchate, Metropolitan Pitirim, has been severely criticised for his generally lax attitude by Literaturnaya gazeta ${ }^{39}$ and even by the patriarch. ${ }^{40}$ Zhurnal Moskovskoi Patriarkhii, the official monthly of the patriarchate, of which Pitirim is editor in chief, has failed to appear outside Russia since 1991, either in Russian or in English, and subscribers have not been notified. Inflation cannot be the problem here since foreign subscriptions are paid in convertible currencies. The main cause must be bad management in the department.

Since January 1993 the Zhurnal Moskovskoi Patriarkhii has been split into two monthly periodicals. One of them bears the subtitle Ofitsial'naya khronika and will contain all official church documents, such as the patriarch's speeches, decisions of the Holy Synod, news of appointments and comment on important matters relating to 
church and society. The other, with the old title, will contain popular and scholarly articles in the fields of ecclesiology, liturgy, hagiography and church history.

\section{Pastoral Care}

From 25 to 27 January 1991 Moscow University was the location for the first 'Allchurch Congress of Orthodox Youth', which founded a church youth movement. This is a completely new medium for pastoral work by the Russian church. The patriarch and Metropolitan Kirill were among those who attended the congress. In their speeches they warned against pseudo-religiosity and pointed out the necessity of a proper link with the hierarchy. Among the tasks of the youth movement are charity work and organising Sunday schools and summer camps. Kirill Yel'chaninov, chairman of the Paris-based Russian Christian Movement, observed that this organisation has fulfilled its task and that from now on it will work closely with the new Russia-based movement. Bishop Aleksandr of Kostroma was elected chairman. He stated in an interview that the newly founded movement will not become a 'church komsomol', centralised and bureaucratic, but will need to be a creative movement within the church. ${ }^{41}$ In due course the administrative centre of the movement will be established in the Krutitskoye Podvor'ye complex, the old residence of the Metropolitan of Moscow. In April 1991 Moscow University was the location for the foundation of the Moscow branch of the youth movement. On this occasion Patriarch Aleksi talked about Russia's great social needs. ${ }^{42}$ The youth movement cooperates closely with the Union of Orthodox Brotherhoods, founded in October 1990, the national organisation of local charitable, educational and cultural lay groups within the church.

On 28 June 1991 Patriarch Aleksi addressed the younger generation in a circular letter. The letter is characterised by a personal style and an open approach to the problems confronting young people in Russia. Among other things, the patriarch criticises abortion; generally he seems to have no illusions about the appeal of Christianity for the young. ${ }^{43}$

One year later, from 2 to 8 June 1992, the newly founded Orthodox Youth Movement in Russia hosted the Fourteenth 'World Assembly' of the Federation of Orthodox Youth, Syndesmos. Apart from the youth movement, representatives of six seminaries in Russia, Ukraine and Belarus also took part. With a view to giving the Russian and other Eastern European Orthodox youth movements an opportunity for a further exchange of experiences a European seminar of Syndesmos was held in Moscow from 8 to 15 November. In December, with the approval of the Holy Synod, an Orthodox Scouting organisation was founded within the Orthodox Youth Movement of Russia.

Regular diocesan meetings are to organise social work and prepare the clergy for pastoral duties. On 11 December 1992 there was a meeting of diocesan council of the city of Moscow in the Danilov Monastery, chaired by Patriarch Aleksi, who is bishop of Moscow by virtue of his office. ${ }^{44}$ The meeting was informed that the eparchy of Moscow comprised a total of 197 parish churches, not counting the Kremlin churches, the 14 chapels and churches in the patriarchal buildings and the 23 churches in the four monasteries. For the time being, regular religious services were held in only 132 parish churches. At that time 334 priests and 96 deacons were actively involved in pastoral work. Thus, since 1988 there had been a fivefold increase in the number of churches while the number of priests had only doubled. During the meeting the patriarch in a frank speech directed criticism at the routine manner in which many priests celebrate the liturgy and administer the sacraments. He called for catechesis to be given to 
prospective married couples and parents before the celebration of marriage and baptism, and insisted on the reintroduction of personal confession and baptism by total immersion. For the latter purpose churches will have to install baptistries. The patriarch also exhorted priests to preach not only in church but also in hospitals, orphanages and prisons, and to be more active in setting up Sunday schools. He concluded by pointing out the precarious financial situation of the church. Soon, on account of inflation, the patriarchate may no longer be able to pay any salaries to parish priests.

The head of the Department for Charity and Social Assistance, Archbishop Sergi of Solnechnogorsk, reported that there were 853,200 persons in the diocese who had received humanitarian aid. Goods sent from abroad for relief were distributed by way of the parishes, which keep lists of those in need.

During 1992 pastoral activities began in previously inaccessible areas: the army, prisons, hospitals and universities. On 29 October 1992 spiritual care in the army was the subject of a discussion between the vice-chairman of the Department for External Church Relations, Archpriest Viktor Petlyuchenko, and two colonels from the Ministry of Defence. The extremist nationalist papers Den' and Russky vestnik also regularly argue in favour of strengthening 'Orthodox consciousness' among the military. Here, however, ideological motives clearly prevail over religious ones. These two newspapers argue not only in favour of army chaplains but also for Orthodox commanders who will supervise compulsory attendance at religious services by their troops. ${ }^{45}$

For the spiritual care of prisoners the Union of Orthodox Brotherhoods has founded a Prison Mission, led by the Moscow lawyer $\mathrm{Zh}$. Vorotnikov and the priest Anatoli Gorbunov. The members send Christian reading-matter to prisoners and maintain contacts with them. In some places prison chapels have been built. There are already ten of these in Moscow. On 11 September 1992, in the camp for long-term prisoners at Metallostroi, in the neighbourhood of St Petersburg, Patriarch Aleksi himself consecrated a small church built by the inmates. More than two years previously, as metropolitan of Leningrad, he had laid the foundation stone and had promised that he would come to consecrate the church when it was finished. The church is dedicated to St Veniamin, the metropolitan of Petrograd who was killed in 1922. ${ }^{46}$ In prison camp No. 33 in St Petersburg 'there is a sky-blue cupola with an Orthodox cross next to a watch-tower with an armed guard'.47 In this case the initiative for spiritual care was taken by the camp authorities themselves. In general, a lot depends on the personal attitude of the prison management: not all of them by any means are prepared to allow freedom of religion in prisons.

Facilities for religious services are also becoming more generally available in hospitals and homes for the elderly. In September 1992 the patriarchate started a training course for Orthodox nurses, run by the Sisters of Mercy, in the St Dimitri School adjoining City Hospital No. 1. On 30 October Patriarch Aleksi and Archbishop Sergi of Solnechnogorsk consecrated a church in a Moscow psychiatric clinic attached to the Russian Academy of Sciences. There the patriarch also signed an agreement on cooperation between the patriarchate and the Academy of Sciences with respect to the care of psychiatric patients in Russia. ${ }^{48}$

The Orthodox Brotherhoods came into being at the end of 1989 and the beginning of 1990, when active faithful men and women organised themselves in local communities with a view to involving themselves in religious-social and catechetical work. The local organisations, now 94 in number, are united in a Union, with the monk Kirill Sakharov as president. From 17 to 19 June 1992 the Union held its third 
national congress in the St Petersburg Theological Academy. The congress was divided by considerable differences of opinion and according to the patriarchate's Informatsionny byulleten' it was sometimes hard to discern a spirit of brotherhood. We are informed about the nature of these differences by Russkaya mysl ${ }^{39}$ The Federation now finds itself in politically extremist and antisemitic circles. A number of militant brotherhoods, including the one led by Vladimir Osipov, want Tsar Nicholas II to be explicitly canonised as a victim of a Jewish conspiracy and the patriarch to apologise for his address to the rabbis in New York in November 1992. Although honorary president of the Union and himself subject to criticism, the patriarch has not yet made any statement with respect to the right-wing radical course of the Union of Orthodox Brotherhoods.

One particular pastoral activity of the Russian Orthodox Church which is worthy of note was its participation, together with Catholics and Old Believers, in a seminar on abortion. It took place in Moscow from 8 to 10 October 1992 and was organised by the international movement Right to Live. The Moscow charity association Nadezhda is setting up a Russian branch of Right to Live. In an appeal to all people of goodwill it called for support for the antiabortion movement. The religious arguments against abortion are understandable, but the arguments used in the Nadezhda appeal are more nationalist and demographic than religious in character.

A terrible evil has been desecrating our once Holy Russia for more than 70 years. Russian mothers have their unborn children killed ... Russia kills its future ... As a nation we are rapidly being extinguished. According to the statistics of the centre for social demography of the Russian Academy of Sciences the population of Russia decreases by more than a million people every year ... If every Christian would save at least one baby once a year, abortion would no longer exist in this country. ${ }^{50}$

\section{Catechesis}

Religious education is the area where the greatest challenge lies for the Russian Orthodox Church; it is its most difficult mission. A Department for Religious Education and Catechesis was founded in 1990 to organise education and create a church intelligentsia. It is now headed by Fr Ioann Ekonomtsev, a broadminded priest and author of the book Pravoslaviye, Vizantiya, Rossiya (Orthodoxy, Byzantium, Russia), first published in Paris in 1989. Religious teaching programmes have been set up on all levels, from Sunday school to university. Little is known about teaching activities in the Russian regions. In Moscow there were more than 50 Sunday schools in 1992 . They operate with a variety of very detailed programmes. ${ }^{51}$

Sometimes Sunday schools are also founded by the management of ordinary schools, and here the patriarchate does not exercise any supervision over the content of religious instruction. In this case there are often lessons in pseudo-religious subjects like occultism, and the lessons are sometimes given by teachers who used to teach atheism at these schools. The patriarchate has received complaints from parents about these unauthorised lessons in religion and has proposed that optional lessons in religion at state schools should be given by teachers appointed by one or another religious denomination.

In addition, Moscow has eleven so-called 'Orthodox gimnazii' (grammar schools) with a more or less complete teaching programme. They have to contend with a lack of material facilities and are still of ambiguous legal status. 
A conference organised by the Department for Religious Education and Catechesis from 8 to 11 June 1992 was attended by the Union of Orthodox Brotherhoods, the Orthodox Youth Movement, and schoolteachers from twelve cities. Educators and other specialists discussed methodological and organisational matters. It was the first big conference on this subject in Russia. There was found to be a contradiction between the great spiritual resources and inadequate economic resources for religious education. One subject for discussion was the relation between religious instruction and the state educational system: is it possible to combine lessons in physics and history with teaching on God's natural revelation and on Providence? How is one to teach moral discipline to the younger generation with its impulsive and uninhibited lifestyle? On 25 August, before the beginning of the new school year, a follow-up meeting was held at the Department for Religious Education. There the Russian viceminister of education, Asmolov, expressed the hope that with the help of the spiritual values of Orthodoxy the church would succeed in training the new generation of children to become responsible, free personalities. There was also a discussion about the expansion of Protestant sects which are trying to fill the spiritual vacuum in Russia.

There has also been cooperation with Protestant churches, however. A conference on religious education organised by the Department for External Church Relations of the Russian Orthodox Church and the World Council of Churches' Department for Mission, Education and Witness took place in Moscow from 15 to 17 June 1992. It was a follow-up to a similar meeting in December 1991. The conference dealt with general problems of Christian education in Central and Eastern Europe and stressed the necessity for an ecumenical approach to evangelisation in today's pluralistic society.

\section{Higher Education}

Two new institutes of higher education in Moscow may turn out to be of great importance for the future of the Orthodox Church in Russia. These are the Orthodox Theological Institute of St Tikhon (Pravoslavny Svyato-Tikhonovsky Bogoslovsky Institut) and the Russian Orthodox University (Rossiisky Pravoslavny Universitet).

The theological institute was founded in March 1992 and started its courses in September of the same year. It is the first theological institute of higher education in Russia for the laity. Students are being trained as teachers of religion, research workers in the fields of religious art, music, architecture and history and diaconal workers in the church. The institute evolved out of a theological-catechetical part-time course which had already been in existence for two years, and from which 130 graduates have started working in Sunday schools and secondary schools. This course is continuing as an evening course alongside the full-time course which has now been added. On 18 September 1992 the institute began with 650 students, more than half of whom were female. Many of them have already completed some kind of higher education. The rector of the institute is Archpriest Vladimir Vorob'yev. ${ }^{52}$

The institute comprises five faculties: pastoral theology; catechesis; pedagogics; icon art and church architecture; church music. Subjects taught include the history of philosophy, classical studies, modern languages, computer science, dogmatic theology, comparative theology (= western theology), moral theology, liturgy, Biblical studies, patristics, icon painting and singing. Many of the teaching staff come from Moscow State University and the Theological Academy at Sergiyev Posad.

For such an elaborate programme and such a large number of students the institute has few material facilities at its disposal. For the time being, lessons are being given in the buildings of Moscow State University - evidence of good relations between the 
academic world and the church. The starting capital was provided by the Orthodox Church of America: this is why Metropolitan Feodosi and Patriarch Aleksi are cochairmen of the board of governors. The institute calculates that it needs $\$ 20,000$ a year - the annual cost of one student in the United States - in order to pay the entire scientific and administrative staff. As yet the institute has hardly any telephones or photocopiers, and no library of its own; for most of the subjects textbooks have still to be written.

The Russian Orthodox University in Moscow has been operating since 15 February 1993. Its aim is not professional training for the church but the training of an Orthodox intelligentsia. The university evolved out of a joint initiative by the Patriarchate and Russian philologists and classicists and is housed in the building of the former Zaikono-Spassky Monastery, which in the seventeenth century was the seat of the Slav-Greek-Latin Academy. It was officially opened by Patriarch Aleksi and the Russian deputy prime minister Boris Saltykov. The rector is Ioann Ekonomtsev.

So far there are three faculties: a philosophical-theological faculty headed by Deacon Andrei Kurayev; a Biblical-patrological faculty headed by the well-known Byzantinist and member of the Academy of Sciences Sergei Averintsev; and a historical-philological faculty, largely consisting of teachers from the classical studies department of Moscow State University. Courses last five or six years; much attention is devoted to classical and modern languages. The university proposes to conduct an open dialogue with modern culture and philosophy on the basis of a Christian worldview. The first year saw an enrolment of 45 students. ${ }^{53}$

Apart from these Orthodox institutes of higher education there are new secular institutes which do research in the field of religious studies. One such is the Russian State University for Humanitarian Studies (Rossiisky Gosudarstvenny Gumanitarny Universitet), housed in the building of the former Party School. At this university a 'centre for comparative study of world religions' was founded in 1992, with ten students. Another is the centre for the philosophy, psychology and sociology of religion called Simvol (Symbol). This centre is internationally and interdenominationally oriented and at its foundation received congratulations from Pope John Paul II and Patriarch Aleksi. ${ }^{54}$

All these institutes, both religious and secular, have to contend with a shortage of literature. More and more reading matter is being published by the church, but most of it by far is of a liturgical, catechetical and hagiographic nature. There is little scholarly literature on theological, Biblical or historical subjects. The newly opened reading rooms of the French-Russian publishing firm YMCA Press may well be of help here. ${ }^{55}$ At the opening of the Moscow office of the periodical Vestnik Russkogo Khristianskogo Dvizheniya, published by YMCA Press, Patriarch Aleksi sent the editor in chief Nikita Struve a note of thanks for the work done by the periodical over the past 70 years.

As well as opening new theological institutes for laymen the Russian Orthodox Church is expanding the number of training institutes for the clergy. The dissolution of the Soviet Union means that the three seminaries in Ukraine and the one in Belarus are now in independent countries, leaving only the seminaries in Moscow, St Petersburg, Stavropol' and Tobol'sk. In July 1992 the Holy Synod founded a fifth seminary in Tomsk. Actually it was the refoundation of a seminary which existed in this city before 1917. A request from the bishop of Omsk to found a seminary in his city as well was turned down. Considerable efforts and resources will be needed to restart the once flourishing seminary at Tomsk and to restore its totally dilapidated buildings. 


\section{Sectarianism}

It is clear, then, that there is an extensive revival of church life in Russia. In spite of the inertia of metropolitans and bishops inherited from the Soviet past, and notwithstanding the difficult financial circumstances, the church is making great efforts to cope with its new tasks. One should not idealise the 'religious renaissance' in postcommunist Russia, however. It is incorrect to speak of an enormous growth of Christianity. A sociological survey in 1991, the results of which became known in the spring of 1992, is particularly revealing: 29 per cent of the people interviewed say they believe in God; 19 per cent of them officially confess the Russian Orthodox belief. ${ }^{56}$ Also sobering is an article by Sergei Lezov in Nezavisimaya gazeta about the gap between the Christian ideal and the traditional Russian church. ${ }^{57}$

A lot of what is presented as 'religious interest' has nothing to do with Christianity. Interest in pseudo-religion and superstition is burgeoning: astrology, anthroposophy, spiritualism, occultism, yoga and the Hare Krishna movement are very popular. Various Christian sects from East and West are also spreading throughout Russia: the Mormons, Moonies, Jehovah's Witnesses and others. In addition to these foreign sects there are Russian sects: the apocalyptic sect of the White Brotherhood (Beloye Bratstvo) and the Centre of the Mother of God (Bogorodichny Tsentr). The latter, founded by ex-priests from the so-called True Orthodox Church (the former Catacomb Church), practises exorcisms in buildings formerly belonging to the Communist Party, proposes to build a chapel devoted to the Holy Virgin Mary on the site of the Lenin Mausoleum and organises conspicuous prayer processions through the city. Its founder Ioann Bereslavsky - who has appointed himself archbishop - claims that he personally receives messages from Mary. He asserts that Mary is the incarnation of the Holy Spirit, that the end of the world is at hand and that God has made a 'third covenant or testament', superseding the Old and New Testaments, in which Mary has taken the place of Christ. The Centre has adopted a Roman Catholic style in its devotion to Mary, with statues, rosaries and references to Lourdes and Fatima. It publishes a small magazine, Rytsar'very (Knight of the Faith). Both the Moscow Patriarchate and the True Orthodox Church have dissociated themselves from this sect and issued warnings about it. The judicial authorities have instituted legal proceedings against the Centre on the grounds that it has been involved in kidnapping minors. ${ }^{58}$

\section{Jurisdictional Problems}

The restoration of religious freedom and the collapse of the Soviet Union have led the Russian Orthodox Church into various jurisdictional conflicts inside Russia and in some former Soviet republics. In 1990 the Russian Orthodox Church Abroad (or the Russian Church 'in exile'), led by Metropolitan Vitali in New York, started setting up parishes in Russia, now calling itself the Free Orthodox Church in Russia, and thus entered into direct confrontation with the Moscow Patriarchate. In February 1991 the Suzdal' priest Valentin Rusantsov, who was the first to go over to the Russian Church Abroad in 1990, was consecrated bishop of Suzdal' in Brussels. In Russia he at first worked with one Lazar, about whom nothing is known except for the fact that he bears the title of 'Archbishop of Moscow and Kashira' and came from the former Catacomb Church, which is now calling itself the True Orthodox Church. ${ }^{59}$ As this splinter church has always led an underground existence, it is very difficult for outsiders to ascertain the true facts about it.

The Russian Orthodox Church Abroad consistently fought the Soviet system. Now 
that this system is no more, the Church Abroad has lost the main reason for its independent existence; but Metropolitan Vitali refuses to reconcile himself with the Moscow Patriarchate. He insists that Patriarch Aleksi should openly condemn his church's cooperation with the Soviet regime. He also requires, as a condition for cooperation, that the Moscow Patriarchate should leave the ecumenical movement, a condition which is of course unacceptable. Vitali's intransigent attitude means that dialogue is impossible. When Patriarch Aleksi paid a visit to the Orthodox Church in America in November 1991, he had no contact with Metropolitan Vitali. ${ }^{60}$ Aleksi has nevertheless made his own efforts to start a dialogue with the Russian Orthodox Church Abroad. He reacted approvingly to an appeal from members of both churches to him and Metropolitan Vitali to strive for reunification and convene an all-Russian church council. ${ }^{61}$ In an open letter of 17 October 1991 he proposed reunification under the Moscow Patriarchate, with complete autonomy for the Russian Church Abroad, while Moscow would give up its present jurisdiction in the West. ${ }^{62}$ In February 1992 a group of 30 priests of the Moscow Patriarchate sent an open letter to Metropolitan Vitali which also contained a call for reconciliation. The letter produced a rather uncompromising reaction on the part of the secretary of the German diocese of the Russian Church Abroad, Nikolai Artemov. ${ }^{63}$

The quarrel between the patriarchate and the emigre Church Abroad gives rise to tragicomic situations. In St Petersburg each of the two churches occupies a part of the church of the Icon of the Mother of God of Kazan': together under one roof, but at odds with each other. ${ }^{64}$ Meanwhile the influence of the Free Orthodox Church in Russia is growing. According to a report from the patriarchate, it already has hundreds of parishes in the area of Moscow and Vladimir-Suzdal'. 65

After the dissolution of the Soviet Union complications arose in relationships between Moscow and the Orthodox churches in the new states. To the Moscow Patriarchate belong the autonomous Orthodox churches in five former Soviet republics: Ukraine, Moldova, Belarus, Latvia and Estonia.

There were dramatic developments in relations between Russia and Ukraine. After the establishment of the sovereign Ukrainian state the then Metropolitan of Kiev, Filaret Denysenko, claimed autocephalic status for the Ukrainian Orthodox Church, which had already become autonomous at the beginning of 1991. This move was perceived as an opportunistic and insincere volte face by a church leader who in Soviet times had gone so far as to forbid the use of the Ukrainian language for sermons in Ukrainian churches. Filaret had moreover been a zealous informer of the Soviet KGB in Ukraine, and this became public knowledge after the opening of the KGB archives in January 1992. ${ }^{66}$ In April 1992 the Bishops' Council of the Russian Orthodox Church, including the Ukrainian bishops, discharged Metropolitan Filaret from office, on the grounds that he had failed to comply with repeated requests on the part of the Holy Synod to give up his schismatic activities. The Council also defrocked Filaret, because of his uncanonical and immoral way of life, revealed in the press by the well-informed journalist Aleksandr Nezhny. ${ }^{67}$ On 27 May, 18 out of the 22 Ukrainian bishops, who wished to preserve canonical ties with the Moscow Patriarchate, elected Bishop Volodymyr (Sobodan) of Rostov as Metropolitan of Kiev and head of the autonomous Ukrainian Orthodox Church. Filaret nevertheless continued his activities, trying to join forces with the Autocephalous Ukrainian Orthodox Church under Patriarch Mstyslav; but this relationship broke down after some months, and there now exist two autocephalous Orthodox Churches in Ukraine alongside the Autonomous Ukrainian Orthodox Church. ${ }^{68}$ In view of the many other urgent problems confronting the churches in Russia and Ukraine, the unseemly struggle 
between Kiev and Moscow, not the first in Russian-Ukrainian history, is a great tragedy not only for the Orthodox churches in the countries involved but for Orthodoxy as a whole.

Between Belarus and Russia there are no jurisdictional problems. The autonomous Orthodox Church of Belarus (ten dioceses and 788 parishes on 1 January 1993) maintains good relations with the Moscow Patriarchate. In September 1992 it celebrated the millennium of Orthodoxy in the one-year-old independent state of Belarus'.

The relationship of the Moscow Patriarchate with the Moldovan Orthodox Church is more complicated. On 5 October 1992 Moscow declared the church in Moldova autonomous and the diocese of Chişinau was given metropolitan status under the leadership of Bishop (subsequently Metropolitan) Vladimir. Meanwhile, however, the Moldovan Bishop Petru, having gone over to the jurisdiction of the Romanian Patriarchate, proclaimed, or rather reproclaimed, the 'Bessarabian Metropolitanate', which had existed from 1920 to 1944 when Moldova was part of Romania. On 20 December 1992 Patriarch Teoctist of Bucharest unilaterally reunited this 'Bessarabian Metropolitanate' with the Romanian Orthodox Church. In spite of the fact that he had the backing of no more than ten of the 700 priests of his church and had meanwhile been dismissed from his post by the Moscow Patriarchate, Petru asked the Moldovan government to recognise him. The government's attitude in this conflict is ambiguous. It does not want Moldova to join Romania, but at the same time wishes to underline the distance between Moldova and Moscow. The government put forward its own suggestion: an autonomous Moldovan church under the Patriarch of Constantinople. Metropolitan Vladimir does not rule out the possibility of completely independent autocephalic status for his church in the distant future. ${ }^{69}$

There have also been changes in church relations between Moscow and the Baltic countries. In August 1992 the Orthodox churches in Estonia and Latvia were declared autonomous by the Moscow Patriarchate, which thus reverted to the declarations by Patriarch Tikhon on 28 June 1920 and 19 July 1921. There is, however, a new conflict which is threatening the Orthodox Church of Estonia from within: a proportion of the believers do not want autonomy under the Moscow Patriarchate, but would prefer the jurisdiction of the Patriarchate of Constantinople. They recall the fact that their church has already joined Constantinople once, in 1923, under the name of the Apostolic-Orthodox Church of Estonia, and that when this church was abolished in 1940 it was under pressure from the Russians. Thus a new ethnic conflict has arisen within Orthodoxy. ${ }^{70}$

In Lithuania, by contrast, there have been no changes. At a meeting on 2 September 1992 the Orthodox clergy 'unanimously decided' 'that there is no need for any change whatsoever in the present canonical status of the Lithuanian diocese in the near future'. This means that the Orthodox Church in Lithuania will remain an archdiocese of the Moscow Patriarchate. It is led by Archbishop Khrizostom, who incidentally is the only one of the Orthodox bishops to have openly admitted his former cooperation with the KGB. ${ }^{71}$

\section{Notes and References}

1 Journal of the Moscow Patriarchate (JMP), no. 9, 1991, p. 20. For the text of the Civil Statute, see $J M P$, no. 10, 1991, pp. 7-15.

2 Information Bulletin of the Department for External Church Relations of the Moscow Patriarchate (IB), no. 2, 1992, pp. 2-4; Russky vestnik, 12 February, 1992, p. 8. 
3 For the manifesto see Sovetskaya Rossiya, 22 December 1990. The signature of Patriarch Aleksi was probably a falsification or at least added through a misunderstanding. See interview with Aleksi in Izvestiya, 30 December 1990. See also the article by Gerd Stricker in Glaube in der 2. Welt, no. 2, 1991, pp. 16-18.

4 Izvestiya, 15 January 1992.

5 Komsomol'skaya pravda, 6 April 1991.

6 Izvestiya, 28 May 1991.

${ }^{7}$ Izvestiya, 10 June 1991. The first critical articles in the church press on the declaration of Metropolitan Sergi appeared one year later in Zhurnal Moskovskoi Patriarkhii (Russian edition), no. $11 / 12$, 1992, pp. 57-75.

8 IB, no. 1,1992 , pp. 14-15.

9 Nezavisimaya gazeta, 1 October 1992; Stolitsa, no. 28, 1992.

10 Put', Mezhdunarodny Filosofsky Zhurnal, no. 1, 1992.

11 Ogonek, no. 18/19, 1992.

12 Den; 15 November 1992.

13 Moskovskiye novosti, 7 March 1993. In this respect it is also worth mentioning that at a trial on antisemitism a Moscow court was unable to find an official witness of the Russian Orthodox Church who was prepared to declare that the Protocols of the Elders of Zion are antisemitic. See Russkaya mysl', 19 March 1993.

${ }^{14}$ Russky vestnik, November 1992. This issue also contains one of Ioann's patriotic sermons.

15 Moskovsky tserkovny vestnik, no. 14/15, 1992; Sovetskaya Rossiya, 29 August 1992.

${ }^{16}$ Nezavisimaya gazeta, 9 June and 27 August 1992; Ogonek, no. 47/49, 1992; Literaturnaya gazeta, 18 November 1992; Moskovskiye novosti, 7 March and 18 April 1993.

17 Moskovskiye novosti, 26 January 1992. See also the issue of 22 March 1992 for conservative reactions to the speech.

18 Sovetskaya Rossiya, 18 February 1993.

19 In an interview in Nezavisimaya gazeta, 16 April 1993, Metropolitan Ioann denies that there is a difference of opinion between him and the patriarch.

20 Moskovskiye novosti, 5 July and 20 September 1992.

${ }^{21}$ Ogonek, no. $42 / 43,1992$, p. 5.

22 IB, no. 40-1, 1991, p. 6.

${ }^{23} J M P$, no. 12, 1991, pp. 14-18.

24 Ogonek, no. 31/33, 1992, p. 14.

${ }^{25}$ Ofitsial'naya khronika, no. 0, 1993, pp. 3-7.

26 IB, no. 27-8, 1991, p. 6; Russkaya mysl', 9 August 1991, p. 9.

$27 J M P$, no. 11, 1991, pp. 22-3.

${ }^{28} I B$, no. 43-4, 1991, p. 5; no. 3, 1992, p. 4.

${ }^{29}$ Moskovsky tserkovny vestnik, no. 18, 1992, p. 6.

${ }^{30}$ Izvestiya, 23 July 1992.

${ }^{31}$ Izvestiya, 12 November 1992.

${ }^{32} J M P$, no. 5, 1991, pp. 4-8; no. 12, 1991, pp. 20-40.

${ }^{33}$ Russkaya mysl'; 10 April 1992; IB, no. 6, 1992.

$34 J M P$, no. 7, 1991, p. 34.

35 Communicated to Patriarch Aleksi in a letter from the President of the Supreme Court of the RSFSR on 22 February 1991. See $J M P$, no. 5, 1991, p. 27. The judicial decision itself was published in Nauka i religiya, no. 5, 1991, p. 27.

36 IB, no. 43-4, 1991; Irénikon, 64, 1991, pp. 499-502.

${ }^{37} I B$, no. $45-6,1991$, pp. $2-3$.

$38 I B$, no. 39,1991 , pp. 5-6; no. 2,1992 , p. 7.

39 Literaturnaya gazeta, 4 December 1991, p. 13.

40 Ofitsial'naya khronika, no. 2, 1993, p. 24.

41 JMP, no. 5, 1991, pp. 19-24.

${ }^{42} J M P$, no. 8, 1991, pp. 53-6.

${ }^{43} J M P$, no. 10, 1991, pp. 52-3. 
Ofitsial'naya khronika, no. 2, 1993, pp. 14-24.

45 Russkaya mysl', 18 December 1992.

${ }^{46}$ Russkaya mysl', 9 October 1992.

47 Zhurnal Moskovskoi Patriarchii, no. 6, 1992, p. 52.

48 Ofitsial'naya khronika, no. 1, 1993, pp. 28-30.

49 IB, 25 August 1992; Russkaya mysl', 7 August 1992.

50 IB, November 1992.

51 Zakon i Zapovedi Bozh'i: Sbornik uchebnykh programm (The Law and God's Commandments. Collection of Teaching Programmes), Moscow, 1992.

52 Vestnik Pravoslavnogo Svyato-Tikhonovskogo Bogoslovskogo Instituta, no. 1; Izvestiya, 18 September 1992; Ofitsial'naya khronika, no. 2, 1993, pp. 26-30.

53 Izvestiya, 20 January 1993.

54 Russkaya mysl', 8 January 1993.

55 Russkaya mysl', 26 March 1993.

56 Informationsdienst Osteuropäisches Christentum, 16 September 1992, pp. 14-15.

57 Nezavisimaya gazeta, 29 October 1992.

${ }^{58}$ Moskovskiye novosti, 14 March 1993. See also Bogoslovsky analiz lzheuchenii 'Bogorodichnogo tsentra' (Theological Analysis of the False Teachings of the 'Mother of God Centre'), Izd. Svyato-Vladimirskogo bratstva, 1992.

59 Glaube in der 2. Welt, no. 6, 1991, pp. 8-9; Informationsdienst Osteuropäisches Christentum, 31 December 1991, pp. 31-2; 31 January 1992, p. 10.

${ }^{60}$ In $I B$, no. 8, 1992, p. 5, the Patriarchate contradicts a foreign report that there had been an attempt to bring the two church leaders into contact with each other.

${ }^{61} J M P$, no. 12, 1991, pp. 4-5.

62 IB, October 1991, pp. 1-2; Informationsdienst Osteuropäisches Christentum, 11 November 1991, p. 35, and 4 December 1991, p. 27.

${ }^{63}$ Russkaya mysl', 20 March 1992, p. 9.

${ }^{64}$ Russkaya mysl', 8 May 1992 and 19 June 1992.

${ }_{65}$ IB, 25 August 1992.

${ }^{66}$ Izvestiya, 22 January 1992; Ogonek, no. 4, 1992, pp. 2-3.

${ }^{67}$ Ogonek, no. 48, 1991, pp. 8-10 and no. 49, 1991, pp. 20-2.

${ }^{68}$ On 24 October 1993 the church faction of Filaret Denysenko established its own patriarchate and elected Metropolitan Volodymyr Romanyuk as patriarch. On 7 September 1993 the other autocephalic Ukrainian Orthodox Church had elected Dymytri Yarema as its new patriarch and successor of the demised Patriarch Mstyslav.

${ }^{69}$ Russkaya mysl', 13 November 1992 and 8 January 1993.

70 Izvestiya, 6 May 1993.

71 Interview in Russkaya mysl', 24 April 1992, pp. 8-9, translated in Religion, State and Society, nos. 3-4, 1993, pp. 345-50. 